\title{
Pembuatan Cockroachtrap dengan Variasi Umpan Sebagai Media Pengundang Kecoa
}

\author{
Firman Aly Meswara ${ }^{1}$, Nurul Fadilah ${ }^{2}$, Wildan Abdurrahman ${ }^{3}$, Nabila Tamrin ${ }^{4}$, Adzan N.M.T.Abd \\ Jurusan Kesehatan Lingkungan, Poltekkes Ternate
}

\begin{abstract}
ABSTRAK
Cockroach is one of insects that could be found in the settlement, it could be a vector for many diseases, it could be found all over the word and related to the men habitation. There are many ways to control cockroach, such as sanitation effort, biological, mechanical or chemical. Trapping method is one of the method to control cockroach by using bait that cockroach favored. The purpose of the study was to know the way to make cockroach trap, the ability of sugar combined with yeast, milk, jam, cheese, meat, egg yolk as cockroach trap. This was an experimental study with post test only designed. Average of cockroach number which were trapped by using meat was 1, jam was 8, milk was 3, sugar+yeast was 1, egg yolk was 2 and cheese was 3. Trapping media (bait) that trapped most cockroach was jam (8 cockroach) while the least were meat and sugar plus yeast (1 cockroach). Based on eating activity, cockroachs were more active in the night.
\end{abstract}

Keywords : Cockroach, Cockroach Trap, Media

\begin{abstract}
ABSTRAK
Kecoa merupakan salah satu hama pemukiman yang menjadi vektor dari berbagai penyakit, tersebar luas di seluruh dunia dan berasosiasi dengan habitat manusia. Pengendalian kecoa dapat dilakukan dengan berbagai cara, seperti secara sanitasi, biologis, mekanis, atau kimiawi. solusi mengendalikan kecoa adalah menggunakan metode trapping dengan menggunakan variasi umpan yang disukai kecoa. Tujuan penelitian ini adalah untuk mengetahui cara membuat alat perangkap kecoa, mengetahui kemampuan gula+ragi, susu indomilk, selai, keju, daging sapi, kuning telur sebagai media perangkap kecoa. Jenis penelitian ini adalah eksperimen dengan rancangan post test only groub design. Hasil pembuatan perangkap dapat dibuat dengan menggunakan bahan toples, pipa 2 inchi, lem. Sedangkan perangkap dengan media daging mampu mengundang kecoa dengan nilai rerata 1 , media selai dengan nilai rerata 8 , media susu dengan nilai rerata 3 , media gula+ragi dengan nilai rerata 1 , media telur dengan nilai rerata 2, media keju dengan nilai rerata 3. Pada penelitian ini jumlah media yang paling banyak mengundang kecoa yaitu media selai yaitu kecoa dengan nilai rerata 8 , sedangkan media yang paling sedikit yaitu pada media daging sapi dan media gula+ragi dengan nilai rerata 1 . Berdasarkan aktifitas makannya, aktifitas makan kecoa lebih beraktifitas dan mencari makan pada malam hari.
\end{abstract}

\section{Kata Kunci : Kecoa, Perangkap Kecoa, Media}




\section{PENDAHULUAN}

Kecoa merupakan salah satu hama pemukiman yang menjadi vektor dari berbagai penyakit, tersebar luas di seluruh dunia dan berasosiasi dengan habitat manusia ${ }^{1}$. Kecoa mempunyai peranan yang cukup penting dalam penularan penyakit. Peranan tersebut antara lain sebagai vektor mekanik bagi beberapa mikroorganisme patogen, inang perantara bagi beberapa spesies cacing,menyebabkan timbulnya reaksi-reaksi alergi seperti dermatitis, Rinitis alergi, gatal-gatal dan pembengkakan kelopak mata. Serangga ini dapat memindahkan beberapa mikroorganisme patogen antara lain, sreptococcus, salmonella dll. Sehingga mereka berperan dalam penyebaran penyakit antara lain, disentri, diare, cholera virus hepatitis A, Polio $^{2}$. Kuncara menyatakan bahwa terdapat hubungan antara rhinitis elergi dengan jumlah populasi kecoa di dalam rumah dan menyatakan bahwa orang yang terkena Rinitis elergi mempunyai risiko terjadinya ISPA $^{3}$.

Kecoa juga dapat menyebabkan Korpus alenium di liang telinga manusia, kecoa dapat memasuki liang telinga manusia. Pergerakan kecoa di liang telinga mengakibatkan perlukaan dinding liang telinga karena kaki serangga yang tajam. trauma mekanik yang ditimbulkan dapat Jurnal Kesehatan Poltekkes Ternate merusak gendang telinga sehingga dapat terjadi ketulian. Selain itu kecoa juga merupakan vektor mekanik bakteri dan parasit sehingga juga dapat menimbulkan infeksi bakteri yang biasanya melekat pada tubuhnya ${ }^{4}$.

Pengendalian populasi kecoa selama ini sangat bergantung pada penggunaan insektisida. Insektisida dapat membunuh kecoak secara cepat, namun pemakaian insektisida yang berlebihan dan tidak terkendali dapat menyebabkan resistensi ${ }^{1}$.

Pengendalian kecoa dapat dilakukan dengan berbagai cara, seperti secara sanitasi, biologis, mekanis, atau kimiawi. Pada umumnya cara kimiawi lebih banyak dilakukan oleh masyarakat seperti penyemprotan atau pengasapan, karena dinilai lebih praktis.

Walaupun, asap yang mengandung insektisida ini dapat menyebar keseluruh ruangan di dalam rumah dan meracuni penghuni rumah. Selain itu metode ini juga dapat meninggalkan residu yang berbahaya bagi manusia. Oleh karena itu, perlu dicari pengendalian lain yang lebih aman terhadap lingkungan dan manusia. Salah satu solusinya adalah menggunakan formulasi umpan.

Langkah awal untuk membuat formulasi umpan tersebut adalah mencari kombinasi umpan yang paling disukai oleh

Volume 11 Nomor 1 Tahun 2018 
kecoa. Imago lebih memilih umpan yang berbentuk padat dengan kandungan air, gula, dan protein yang tinggi, serta memiliki bau yang menyengat seperti hasil fermentasi. Selain itu imago kecoa juga menyukai telur ayam karena imago memiliki mandibel yang kuat dan bergigi sehingga mampu mengkonsumsi makanan yang berbentuk padat ${ }^{5}$. Kecoa menyukai makanan yang banyak mengandung gula dan lemak ${ }^{2}$.

Maka berdasarkan latar belakang di atas penelitian ini diharapkan dapat memberikan informasi tentang membuat alat perangkap kecoa serta kemampuan berbagai umpan untuk mengundang kecoa dalam upaya pengendalian.

\section{METODE PENELITIAN}

Jenis penelitian ini adalah eksperimen dengan rancangan post test only groub design. Dengan membandingkan umpan cockroach trap gula+ragi, susu indomilk, selai, keju, daging sapi dan kuning telur dalam mengundang datangnya kecoa. Sampel vektor uji pada penelitian ini adalah 100 imago kecoa untuk setiap kali pengulangan pengulangan dilakukan selama $4 \mathrm{x}$ yang didapatkan dari rumus

$$
\mathrm{p}(\mathrm{n}-1) \geq 16
$$

\section{Keterangan :}

$\mathrm{p}=$ Jumlah perlakuan

Jurnal Kesehatan Poltekkes Ternate

$$
\begin{array}{ll}
\mathrm{n} & =\text { Jumlah pengulangan } \\
16 & =\text { Konstanta }^{7} \\
& \text { Metode pengumpulan data }
\end{array}
$$
dilakukan dengan melakukan observasi pengamatan jumlah kecoa yang terperangkap di berbagai media. Pengamatan dilakukan pada pukul 18.00 WIT dan 08.00 WIT.

Pengumpulan data dikumpulkan berdasarkan jenis media perangkap dan diolah dengan cara membandingkan banyaknya kecoa yang terperangkap pada media umpandan disajikan dalam bentuk tabel dan narasi

Penelitian dilakukan dengan cara :

1. Disediakan kandang uji

2. Dimasukkan imago kecoa kedalam kandang (belum ada media uji) setiap pengulangan berisi 100 imago kecoa

3. Dipersiapkan alat perangkap dengan bahan media uji

4. Diletakkan alat dan bahan media uji di sudut kandang pukul 00.00 (peletakkan media dilakukan secara random)

5. Dilakukan pengamatan seperti yang ditentukan

6. Dilakukan pengulangan selama $4 \mathrm{x}$ 
HASIL DAN PEMBAHASAN

Bahan :

toples, lem, pipa 2 inchi

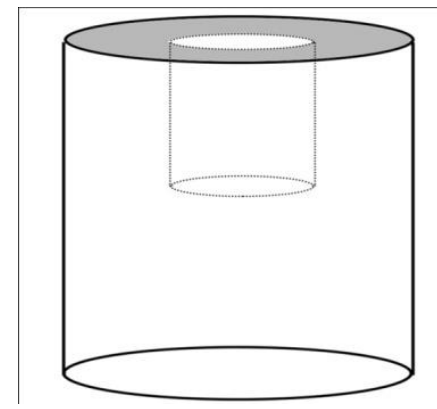

Gambar 1. Design CockroachTrap

Tabel 1. Distribusi Frekuensi Kecoa Yang Terperangkap Berdasarkan Media

\begin{tabular}{|c|c|c|c|c|c|c|c|c|}
\hline $\begin{array}{c}\text { JENIS } \\
\text { OBSERVA } \\
\text { SI }\end{array}$ & Waktu & $\begin{array}{c}\text { CT 1 } \\
\text { (Daging } \\
\text { ) }\end{array}$ & $\begin{array}{c}\text { CT } 2 \\
\text { (Selai) }\end{array}$ & $\begin{array}{c}\text { CT } 3 \\
\text { (Susu) }\end{array}$ & $\begin{array}{c}\text { CT } 4 \\
\text { (Gula+ } \\
\text { Ragi }\end{array}$ & $\begin{array}{c}\text { CT } 5 \\
\text { (Telur } \\
\text { ) }\end{array}$ & $\begin{array}{c}\text { CT6 } \\
\text { (keju) }\end{array}$ & $\begin{array}{c}\text { TOTA } \\
\text { L }\end{array}$ \\
\hline \multirow{2}{*}{ U P } & $08.00 \mathrm{WIT}$ & 0 & 12 & 8 & 2 & 3 & 1 & 26 \\
\hline & 17.00 WIT & 0 & 2 & 0 & 1 & 1 & 0 & 4 \\
\hline \multirow{2}{*}{ P 1} & $08.00 \mathrm{WIT}$ & 2 & 22 & 1 & 2 & 2 & 2 & 31 \\
\hline & 17.00 WIT & 3 & 2 & 2 & 1 & 0 & 5 & 13 \\
\hline \multirow{2}{*}{ P 2} & 08.00 WIT & 0 & 0 & 1 & 0 & 0 & 0 & 1 \\
\hline & $17.00 \mathrm{WIT}$ & 0 & 2 & 2 & 0 & 0 & 1 & 5 \\
\hline \multirow{2}{*}{ P 3} & $08.00 \mathrm{WIT}$ & 0 & 0 & 0 & 0 & 0 & 4 & 4 \\
\hline & 17.00 WIT & 0 & 0 & 0 & 0 & 1 & 0 & 1 \\
\hline \multirow{2}{*}{ P 4} & $08.00 \mathrm{WIT}$ & 0 & 1 & 0 & 0 & 5 & 2 & 8 \\
\hline & $17.00 \mathrm{WIT}$ & 0 & 0 & 0 & 0 & 0 & 0 & 0 \\
\hline Jumlah & & 5 & 41 & 14 & 6 & 12 & 15 & \\
\hline Rerata & & 1 & 8 & 3 & 1 & 2 & 3 & \\
\hline
\end{tabular}

Sumber : Data Primer

Berdasarkan jenis medianya jumlah pada penelitian ini jumlah media yang paling banyak mengundang kecoa yaitu media selai yaitu berjumlah 41 kecoa Jurnal Kesehatan Poltekkes Ternate dengan nilai rerata 8 , sedangkan media yang paling sedikit yaitu pada media daging sapi dan gula+ragi dengan nilai rerata 1 .

Kecoa memakan semua jenis makanan yang dikonsumsi oleh manusia, Volume 11 Nomor 1 Tahun 2018 
terutama yang mengandung gula dan lemak $^{2}$. pada dasarnya kecoa sangat membutuhkan nutrisi untuk pertumbuhan, perkembangan dan reproduksi. Hal inilah yang memungkinkan adanya preferensi dalam memilih makanan. Faktor nutrisi juga memberikan efek jangka pendek dan jangka panjang pada perkembangan dan reproduksi kecoa. Sekalipun keperluan nutrisi sebagian besar serangga hampir sama tetapi tipe dan proporsi nutrisi yang optimal berbeda tergantung spesies dan tahap reproduksi ${ }^{5}$.

Pada tabel 1. bahwa jumlah media yang paling banyak mengundang kecoa adalah media selai. Meskipun berdasarkan hasil penelitian ini yang dapat dilihat pada tabel 1. Nilai rerata tidak berbeda nyata dengan umpan yang lainnya, tetapi jenis umpan yang paling disukai kecoa adalah umpan selai. tidak ada perbedaan yang cukup nyata ini dikarenakan kecoa memakan semua media yang digunakan sebagai umpan ${ }^{5}$. Pada penelitannya pada tahun 2010 yang menggunakan beberapa variasi umpan sebagai media pengundang kecoa. frekuensi kehadiran nimfa pada setiap kombinasi umpan dengan metode pilihan, kecoa lebih banyak ditemukan pada selai stroberi karena memiliki kandungan air, gula, dan protein yang tinggi ${ }^{5}$.
Tabel 2. Distribusi Jumlah Kecoa yang Terperangkap Berdasarkan Aktifitas Makannya

\begin{tabular}{lcc}
\hline Observasi & $\begin{array}{c}\text { Malam } \\
\text { hari }\end{array}$ & $\begin{array}{c}\text { Siang } \\
\text { hari }\end{array}$ \\
\hline Uji Pendahuluan & 26 & 4 \\
Pengulangan 1 & 31 & 13 \\
Pengulangan 2 & 1 & 5 \\
Pengulangan 3 & 4 & 1 \\
Pengulangan 4 & 8 & 0 \\
\hline Total & $\mathbf{7 0}$ & $\mathbf{2 3}$ \\
\hline
\end{tabular}

Sumber : Data Primer

Pada tabel 2. Dapat dilihat bahwa hasil jumlah kecoa yang terperangkap berdasarkan aktifitas makannya jumlah kecoa yang terperangkap pada aktifitas malam hari yaitu 70 kecoa. Sedangkan aktifitas siang hari yaitu 23 kecoa.

kecoa lebih beraktifitas dan mencari makan pada malam hari. Dapat dilihat pada tabel 2. Jumlah kecoa yang terperangkap lebih banyak pada aktifitas malam hari. Ini dikarenakan kecoa merupakan hewan nokturnal yaitu hewan yang aktif pada malam hari. Kecoa pada umumnya menghindari cahaya dan pada siang hari bersembunyi di tempat yang gelap dan sering bersembunyi di cela-cela ${ }^{2}$.

Pengendalian kecoa dengan metode trapping dengan menggunakan variasi umpan sebagai media kecoa memang praktris dan gampang dalam 
pelaksanaannya, dan mampu menangkap kecoa. tetapi untuk menangkap seluruh / total kecoa masih kurang efektif karena dapat dilihat pada hasil penangkapan kecoa pada tabe 1 . dengan nilai rerata paling tinggi 8 kecoa dari 100 kecoa yaitu media CT 2 dengan menggunakan selai. metode trapping kecoa secara komersil selain digunakan sebagai pemberantasan kecoa, juga dapat digunakan sebagai alat monitoring keberadaan kecoa $^{2}$.

Memonitoring keberadaan kecoa sangatlah penting dilakukan, untuk mengetahui keberadaan kecoa di rumah, tempat-tempat umum, rumah sakit dll. Sebagai gambaran tingkat sanitasi tempat tersebut. Berdasarkan Kepmenkes RI No. 1204 Tahun 2004 tentang sanitasi rumah sakit disebutkan bahwa semua ruangan di rumah sakit harus bebas dari kecoa. membuat standar kepadatan kecoa dirumah sakit antara lain : jika ditemukan keco a $\geq 1$ ekor di dalam ruangan maka tingkat kepadatan kecoa dikategorikan sebagai padat. Dan jika tidak ditemukan kecoa di dalam ruangan maka dikategorikan sebagai tidak padat ${ }^{2}$. Maka untuk memonitoring keberadaan kecoa bisa dilakukan dengan menggunakan perangkap kecoa dengan menggunakan umpan

\section{KESIMPULAN}

Berdasarkan dari penelitian ini dapat disimpulkan bahwa pembuatan Jurnal Kesehatan Poltekkes Ternate perangkap kecoa dapat dilakukan dengan bahan dari toples, pipa 2 inch, lem. Sedangkan untuk media perangkap kecoa dengan media daging mampu mengundang kecoa dengan nilai rerata 1 , media selai dengan nilai rerata 8 , media susu dengan nilai rerata 3, media gula+ragi dengan nilai rerata 1 , media telur dengan nilai rerata 2 , media keju dengan nilai rerata 3. Maka media yang paling banyak mengundang kecoa yaitu media selai.

\section{SARAN}

Disarankan kepada penelitian selanjutnya untuk mencoba variasi umpan lain dengan design perangkap yang berbeda dan mencoba mengaplikasikan di lapangan. Meskipun perangkap ini tidak dapat memerangkap seluruh kecoa yang dijadikan hewan uji. Tetapi alat ini dapat digunakan untuk memonitoring kecoa

\section{DAFTAR PUSTAKA}

1. Jannatan, Robby.Dkk. 2013.Laju Respirasi Kecoak Jerman (Blattella germanica, Dictuoptera : Blattelilidae) yang resisten terhadap Insektisida. Jurnal Biologi Universitas Andalas. 2(4) Desember 2013 : 262-268 : (ISSN : 2303-2162). [Diakses : 16 Desember 2016]

2. Sucipto, Cecep Dani. 2011. Vektor Penyakit Tropis. Yogyakarta : Gosyen Publishing 
3. Kuncara, Rido Jati. 2011. Hubungan Rinitis Alergi Dengan Kejadian Infeksi Saluran Pernafasan Atas Akut Episode Sering. (Skripsi). Universitas Dipenegoro : Fakultas Kedokteran

4. Pieter, Richard. 2008.Kecoa Sebagai Korpus Alineum pada Liang Telinga Seorang Awak Kapal. Majalah kedokteran FK UKI, Vol XXVI No.2

5. Amalia, Herma dan Idham Sakti Harahap.2010. Preferensi Kecoa Amerika Periplaneta Americana (L.)(Blattaria: Blattidae) terhadap berbagai kombinasi umpan.Jurnal Entomologi Indonesia. September 2010, Vol. 7, No. 2, 67-77[Diakses : 16 Desember 2016]

6. Keputusan Menteri Kesehatan Republik Indonesia No 1204 Tahun 2004 Tentang Persyaratan Kesehatan Lingkungan Rumah Sakit

7. Haditomo, Indrianto. Efek Larvasida Ekstrak Daun Cengkeh (Syzygium Aromaticum L.) Terhadap Aedes Aegypti L. (Skripsi). Universitas 11 Maret : Fakultas Kedokteran 